\title{
Diet selectivity in relation to food quality and availability by the endemic Perote squirrel (Xerospermophilus perotensis)
}

\author{
Julio C. Hernández-Hernández ${ }^{1}$, Jorge E. Morales-Mávil ${ }^{1}$, Matthias Laska ${ }^{2}$ and Laura T. Hernández-Salazar ${ }^{1 *}$ \\ ${ }^{1}$ Laboratorio Biología de la Conducta, Instituto de Neuroetología, Universidad Veracruzana. Av. Dr. Luis Castelazo Ayala s/n, \\ Colonia Industrial Ánimas, CP. 91190, Xalapa. Veracruz, México. Email: biol.julio@gmail.com (JCHH), jormorales@uv.mx (JEMV), \\ herlatss@gmail.com (LTHS). \\ ${ }^{2}$ IFM Biology, Section of Zoology. Linköping University, SE-581 83, Linköping, Sweden. Email: malas@ifm.liu.se (ML). \\ *Corresponding author
}

Climatic fluctuations have a biogeochemical effect on food availability and quality, resulting in adjustments of the foraging and food selection behavior of animals. Our study aimed to evaluate the influence of seasonal variation on abundance of food resources and its effect on food selection of Xerospermophilus perotensis, an endemic species of ground squirrel in the Oriental Basin. Food selection behavior was recorded using focal animal and continuous behavior sampling on a squirrel population inhabiting the grassland of a semi-arid area. The results show that their diet consisted of 6 plant species with significant differences in the time spent feeding on each plant species $\left(X^{2}=128.96 ; P=0.01\right)$. The species with the highest feeding times included Scleropogon brevifolius (63.6 \%), Verbena bipinnatifida (10.6\%) and Erigeron pubescens (10.5 \%). These plant species had the highest percentage of vegetation cover and availability among seasons, but they were of low nutritional quality with regard to their protein/fiber ratio. However, during specific periods, associated either with gestation and lactation or prior to hibernation, the squirrels increased their protein consumption. This suggests that squirrels are opportunistic feeders, and under certain conditions tend to select plant species that provide them with better quality diets.

Las fluctuaciones climáticas tienen un efecto biogeoquímico sobre la calidad y la disponibilidad de los alimentos, lo que resulta en ajustes en la conducta y la selección de los alimentos de los animales. Nuestro objetivo fue evaluar la influencia de la variación estacional en la abundancia de los recursos alimenticios y su efecto sobre la selección de alimentos por Xerospermophilus perotensis, una especie de ardilla endémica de la Cuenca Oriental. La conducta de alimentación se registró utilizando un muestreo animal-focal con registro continuo en una población de ardillas que habita en los pastizales de una zona semiárida. Los resultados mostraron que su dieta consistió en 6 especies de plantas con diferencias significativas en el tiempo de alimentación de cada especie $\left(X^{2}=128.96 ; P=0.01\right)$. Las especies con los mayores tiempos de alimentación fueron Scleropogon brevifolius (63.6\%), Verbena bipinnatifida (10.6\%) y Erigeron pubescens (10.5\%). Estas especies de plantas tuvieron el mayor porcentaje de cobertura vegetal y disponibilidad entre estaciones, pero fueron de baja calidad nutricional con respecto a su relación proteína / fibra. Sin embargo, durante períodos específicos, asociados con la gestación y la lactancia o antes de la hibernación, las ardillas aumentaron su consumo de proteínas. Esto sugiere que las ardillas son consumidores oportunistas, y bajo ciertas condiciones tienden a seleccionar especies de plantas que les proporcionen dietas de mejor calidad.

Key words: Diet; endemism; ground squirrel; nutritional quality; seasonal variation.

๑) 2018 Asociación Mexicana de Mastozoología, www.mastozoologiamexicana.org

\section{Introduction}

Seasonality refers to recurrent climatic variations that tend to occur over an annual period. These variations define the type of vegetation that exists in a place and directly affect the abundance and quality of food resources (Schaik and Brockman 2005). Such seasonal variations in food abundance and quality have been reported to cause concurrent alterations in the abundance and/or dietary habits of herbivorous species (Gutiérrez 1998; Hirsch 2009; GarcíaGarcía and Santos-Moreno 2014; Penezić and Ćirović 2015; Tsindi et al. 2016).

Although herbivory is largely determined by external factors that regulate food abundance and availability, dietary flexibility plays an important role as it depends on individual digestive processes that regulate the acquisition of metabolizable energy and nutrients (Karasov et al. 1986). In this way, the chemical characteristics of the food directly affect the selection of the diet of the animals, and a preference for certain types of food can be the consequence of its chemical composition (Ulappa et al. 2014). In this context, each animal faces the dilemma of having to obtain an adequate food in terms of quantity and quality to meet its nutritional needs, and protein and fiber are considered the chemical constituents that determine this preference (Stephens and Krebs 1986; Grier and Burk 1992; Rezsutek and Cameron 2011).

Within nutritional ecology there are four hypotheses with regard to the aims of diet selection, each of which proposes that dietary selection has a different nutritional primary objective: 1) maximization of energy uptake (Schoener 1971). 2) The maximization of nitrogen uptake (Mattson 1980; White 1993). 3) Toxin evasion (Freeland and Janzen 1974; Dearing et al. 2005). 4) The acquisition of a nutritionally balanced diet (Raubenheimer and Simpson 2004, Robbins et al. 2007). The quantification of these different nutritional goals is a challenge, especially in studies of wild animals, where research requires detailed data on feeding behavior 
of animals over continuous periods, adequate analysis of all food consumed, and an analytical framework to address the complex nature of nutritional data (Felton et al. 2009).

In fact, the diet of herbivorous mammals is considered one of the most complex in comparison with that of other dietary specialists (Belovsky 1978; Owen-Smith and Novellie 1982). This notion is supported by the fact that herbivores can consume foods in high abundance but of low quality, which often lack essential nutrients, so that they require supplementary intake of different food items to maintain nutritional balance (Westoby 1978).

In semi-arid environments, herbivores must develop even more efficient strategies for harnessing food resources, as the supply of quality vegetation is usually low. These strategies are both behavioral (ability to select proper feeding sites and selection of dietary components) and physiological (development of a digestive system that optimizes food processing; Benítez et al. 2006). Ground squirrels that live in semi-arid environments are therefore a good model to study because of the selectivity of their diet in relation to its quality and availability, which varies seasonally (Valdés 2003).

The ground squirrel of Perote (Xerospermophilus perotensis) is an endemic species of the semi-arid area of the state of Veracruz, Mexico (Best and Ceballos 1995). It has been classified as threatened in the Official Mexican Standard 059 (SEMARNAT, 2010), and as endangered species on the IUCN Red list (Álvarez-Castañeda et al. 2016). During the winter the squirrels encounter low food availability and remain inactive for 2 to 3 months (Valdéz and Ceballos 1997).

Perote's squirrel is adapted to the semi-arid environment, Xerophile shrubland with associations of rosetophilous shrubs, nopaleras, izotal and spiny shrubs with terminal spines. This environment greatly limits the consumption of quality food and adequate nutrient intake. To our knowledge studies on Perote's squirrel have so far focused on aspects related to their ecology and behavior, however, they have not addressed ecophysiological or nutritional aspects. The aim of this study was therefore to investigate the availability, selection and energetic-nutritional content of the diet of $X$. s. perotensis according to seasonal variations, with the purpose of knowing if there is a relationship between the quality of the diet, its consumption, and the adequacy to cover certain physiological demands, using protein as a measure of nutritional quality.

\section{Materials and methods}

Study area. The study was carried out in a semi-arid area in the Valley of Perote, Veracruz, Mexico (19 $34^{\prime} 54^{\prime \prime} \mathrm{N},-97^{\circ}$ $21^{\prime} 55^{\prime \prime} \mathrm{W}$ ). According to the Köppen climate classification, modified by García (1973), the study area has a climate Bs, $\mathrm{K}^{\prime} \mathrm{w}^{\prime}\left(\mathrm{i}^{\prime}\right)$, which is the most humid among semi-arid climates, temperate with warm, rainy summers, and little atmospheric temperature range.

A sampling zone was established in a 3.5 ha grassland area. The natural vegetation of the zone is xerophile shru- bland (Velázquez et al. 2016), where areas covered with different types of vegetation like spiny shrub with lateral spines, cardonales, spineless parvifolia shrub, also identified such as "izotal" (Nolina parviflora and Yucca periculosa), shrubs (Agave obscura), grasslands (Distichlis spicata, Bouteloua hirsuta and Suaeda nigra), nopal fields or "nopalera" (Opuntia robusta, $O$. tunicata, O. huajuapensis and Mammillaria discolor). In addition, herbaceous species such as Salvia microphylla, Dalea alopecuroides, Bouvardia ternifolia, Tagetes micrantha and grass of the species Aristida barbata (Miranda and Hernández 1963; Sandoval 1984) occur in this region.

Behavioral record. The composition of the squirrels' diet was obtained through field observations, aided by Bushnell binoculars $(10 \times 50)$ and a monocular $(12 \times 50)$ from a maximum distance of $20 \mathrm{~m}$. The observation schedule began at 8:00 $\mathrm{h}$ (time when the squirrels began their activity) until 16:00 $\mathrm{h}$ (when activity decreased). We collected data using 5-min focal animal observations (Martin and Bateson 1993) combined with a continuous recording method. Feeding behavior was considered when an individual manipulated and consumed a plant. Although no particular individuals were identified a record sheet was used, recording the duration (seconds) of the feeding and the plant species used as food. Data collection was performed for eight days on a monthly basis, starting in April and ending in November 2010, with a total sampling time of 464 hours.

Collection and identification of the plant species. The plants that the squirrels used as food were collected in the study area and identified in the Herbarium XAL of Instituto de Ecología A.C. Since the squirrels did not do any discrimination between parts of the plant for consumption, all the plant samples (with exception of the fruits of Yucca periculosa) were whole plant of each of the identified species. The plant species were cut at ground level, weighed and later kept in paper bags to be taken to the laboratory for chemical analysis.

Determination of food availability. Two squares of 10 $x 10 \mathrm{~m}$ were established to record plant food availability, and were sampled in May, August and November. Samples were collected and botanized from 20 places of $1 \mathrm{~m}^{2}$ that were randomly selected. Afterwards, the Braun-Blanquet scale of coverage-abundance was used to evaluate the percent of vegetation coverage for each plant species (Wikum and Shanholtzer 1978). The resulting values were converted to percentages of area for each of the plant species considered.

Analytical methods. The plant species that constituted the squirrels' diet were analyzed through proximate chemical analysis, Dry matter (DM), crude protein (CP, N x 6.25), ether extract (EE; AOAC 1990), neutral detergen fiber (NDF), acid detergent fiber (ADF), cell content (CC), hemicellulose $(H)$, cellulose $(C)$ and lignin ( $L$; Van Soest 1967). Duplicate analyses followed the AOAC (2012) guidelines. The content of dry material was determined by drying the plants in a forced air oven until reaching a constant weight after three 
measures. We estimated the dry weight by determining the difference of the water content value.

Evaluation of diet quality. The protein-fiber ratio was calculated as an estimate of the nutritional value of the plant species, in which the total percent of crude protein was divided by the value of the acid detergent fiber (ADF; Chapman and Chapman 2000; Table 3). A nutrient intake rate was used, which considers the proportion of plant matter ingested by the squirrels and its corresponding nutritional value. The relative frequency of each of the plant species consumed by the squirrels was used and the nutrient intake rate was calculated as indicated in the following formula: Nutrient intake rate $=$ nutritional value of the plant species (\%) * relative frequency consumed. Based on the estimates of the nutrient ingestion rate of each plant species, the total nutrient contribution was calculated per month:Total nutrient intake rate $=\Sigma$ nutrient intake rates of each plant species per month / total of consumed species.

Statistical Analysis. To determine the feeding time dedicated to each plant species used by $X$. perotensis, as well as for each of the months of data collection, descriptive statistics were used. Afterwards, the difference between the percentage use of each plant species for each month was calculated, and since the data did not comply with the normality and homogeneity of variances test, the Kruskal-Wallis test and Tukey's post hoc tests were applied to verify the statistically significant differences between the analyzed factors. The confidence level was $95 \%$.

Food availability was measured as percentage of plant cover in May, August and November. To determine the changes in plant species availability across months, a Friedman test was applied.

\section{Results}

Behavioral record. In the study area 14 plant species within six families were recorded. $X$. perotensis used six plant species as a food resource. Considering the average time spent on feeding per food item the squirrels spent $63.60 \%$ on the indigenous grass species Scleropogon brevifolius, followed by Verbena bipinnatifida with $10.60 \%$, and Erigeron pubescens with $10.50 \%$ and Croton sp. with $6.69 \%$. Fruits of Bouteloua scorpioides and Yucca periculosa were included in the diet during September to November, because the fruiting and flowering occurs during these months of the year, with an average percent of time feeding of $2.3 \%$ and $6.1 \%$ respectively (Figure 1 ).

There was a significant difference in the time spent feeding on different plant species $\left(X^{2}=128.96 ; P=0.01\right)$. Pairwise post hoc test revealed that squirrels spent significantly more time feeding on S. brevifolius compared to all other plan species $(P=0.001)$. The foraging time per month varied across the different months of the study. The squirrels devoted a higher percentage of their daily activity budget on feeding during April (22.7\%), May (21\%) and July (21 $\%)$, compared to August (17.5\%) and September (17.6\%; Figure 2A).

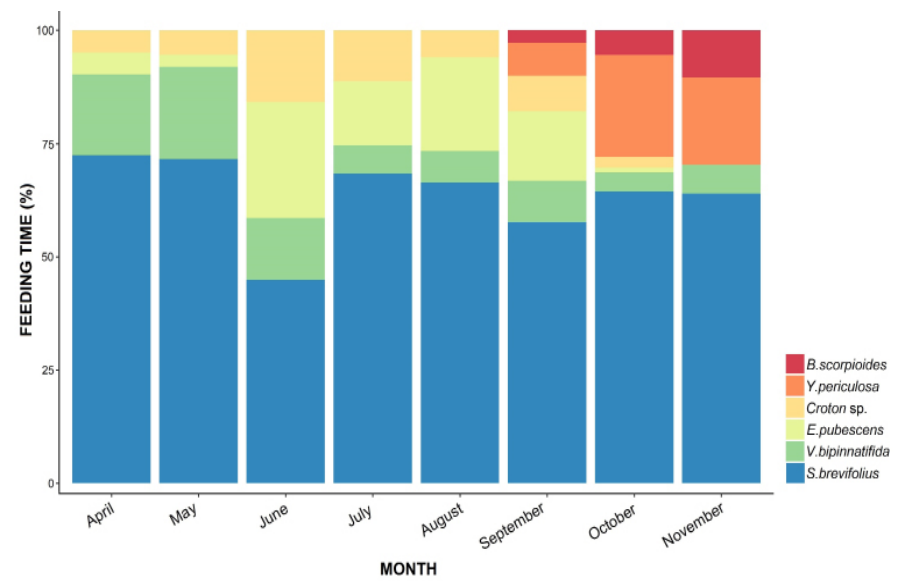

Figure 1. Average percent of time spent on feeding on each of the plant species included in the diet of the squirrels.

Plant species availability and food selection. The plant species with the widest cover were S. brevifolius, E. pubescens, Croton sp. and V. bipinnatifida, which were part of the diet of the squirrels (Table 1). The percentage of the vegetation cover of

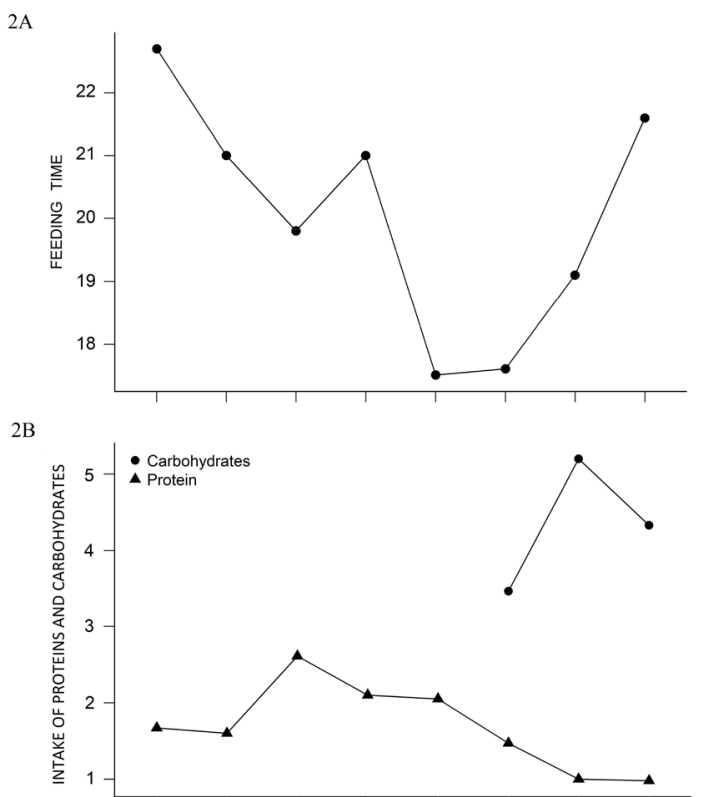

$2 \mathrm{C}$

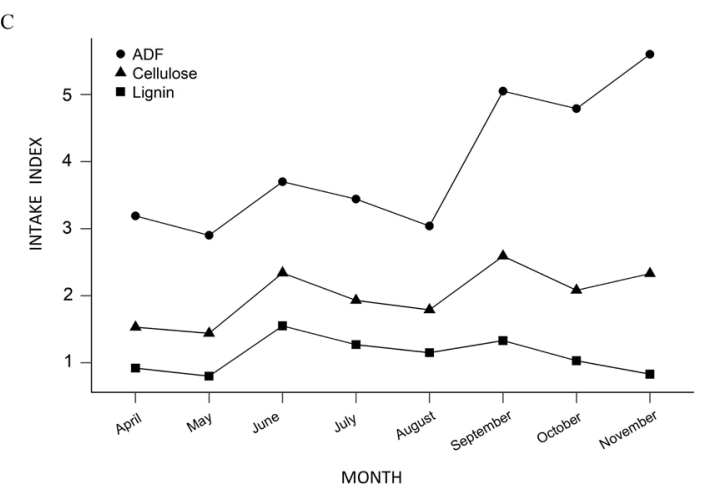

Figure 2. Percentage of feeding time per month considering all plant species used in Perote squirrels diet (A). The protein and carbohydrate index shows that during the recorded period the squirrels ate foods containing mainly protein, while during the months of September, October and November they ingested carbohydrates, due to fruiting and consumption the fruits of $Y$. periculosa (Carbohydrate data from: Baraza et al. 2008) (B). Intake Index of ADF (Acid Detergent Fiber), Cellulose and Lignin for X. s. perotensis. The ADF consumption was higher than the others (C). 
the species that were part of the squirrels' diet showed significant changes during the months in which this variable was recorded $\left(X^{2}=6.50\right.$, d. f. $\left.=2, P=0.039\right)$, and post hoc comparison revealed significant differences between the months of August and November $(P<0.05)$ but no significant differences between May and August, and May and November.

Evaluation of diet quality. The total nutrient intake rate was calculated per month (Table 2). The protein intake rate varied during the data collection period. During April and May, the protein intake was $1.67 \%$, increased in June to $2.61 \%$, July and August (2.10\% and $2.50 \%$, respectively) and decreased

Table 1. Availability of plant species expressed as percent of cover. The species marked with an asterisk $\left.{ }^{*}\right)$ were part of the diet of $X$. s. perotensis.

\begin{tabular}{|c|c|c|c|}
\hline & \multirow{2}{*}{\multicolumn{3}{|c|}{$\%$ Cover }} \\
\hline & & & \\
\hline \multirow[t]{2}{*}{ Species } & May & August & November \\
\hline & \multicolumn{2}{|c|}{ Compositae } & \\
\hline Erigeron pubescens* & 3.9 & 16.6 & 6.8 \\
\hline Gnaphalium gracile & 0.6 & 1.5 & 0.3 \\
\hline Gnaphalium stramineum & 0.3 & 1.1 & 0.7 \\
\hline \multirow[t]{2}{*}{ Bidens laevis } & 0.4 & 0.7 & 0.1 \\
\hline & \multicolumn{2}{|c|}{ Euphorbiaceae } & \\
\hline Croton sp.* & 4.9 & 6.5 & 3.3 \\
\hline \multirow[t]{2}{*}{ Chamaesyce prostrata } & 0.8 & 0.5 & 1.2 \\
\hline & \multicolumn{2}{|c|}{ Leguminosae } & \\
\hline \multirow[t]{2}{*}{ Leguminosa } & 0 & 0 & 0.2 \\
\hline & \multicolumn{2}{|l|}{ Poaceae } & \\
\hline Scleropogon brevifolius* & 49.2 & 54.3 & 39.3 \\
\hline Bouteloua gracilis & 0 & 0.9 & 1.1 \\
\hline Bouteloua scorpioides* & 0 & 0 & 1.8 \\
\hline Distichlis spicata & 0.5 & 0.4 & 1.3 \\
\hline \multirow[t]{2}{*}{ Aristida divaricata } & 0.7 & 0.3 & 0.6 \\
\hline & \multicolumn{2}{|c|}{ Tetrachondraceae } & \\
\hline \multirow[t]{2}{*}{ Polypremum procumbens } & 0 & 0.7 & 0.5 \\
\hline & \multicolumn{2}{|c|}{ Verbenaceae } & \\
\hline Verbena bipinnatifida* & 4.4 & 5.9 & 1.6 \\
\hline
\end{tabular}

during following months (September to November). For this study, the carbohydrate content of plants was not evaluated, however, the percentage of soluble carbohydrates in the fruits of $Y$. periculosa have been reported previously by Baraza et al. (2008) are included in (Figure 2B). According to the consumption of Acid Detergent Fiber, there was an increase during the sampling period, being most notable in the months of September (5.05\%) and November (5.60 $\%)$. In the case of cellulose, the percentages remained constant, increasing slightly in the months of June $(2.34 \%)$ and September (2.59\%), in the same way it happened for lignin, where an increase was shown for the month of June (1.55 $\%$; Figure $2 \mathrm{C}$ ).

The plant species consumed by the squirrels was mainly supplied by E. pubescens, Croton sp. and V. bipinnatifida, which contained the highest protein values $(13.43 \%$ to $15.06 \%)$. Fiber content differed markedly between plant species and ranged from $18.23 \%$ to $74.96 \%$ for neutral
Table 2. Percentage of nutrient intake rate per month by $X$. s. perotensis

\begin{tabular}{lrrrrrrrrr} 
& \multicolumn{10}{c}{ MONTH } & & \\
& & April & May & June & July & August & September & October & November \\
\hline ADF & 3.19 & 2.9 & 3.7 & 3.44 & 3.04 & 5.05 & 4.79 & 5.60 \\
Cellulose & 1.53 & 1.44 & 2.34 & 1.93 & 1.79 & 2.59 & 2.08 & 2.33 \\
Lignin & 0.92 & 0.8 & 1.55 & 1.27 & 1.15 & 1.33 & 1.03 & 0.83 \\
Protein & 1.67 & 1.6 & 2.61 & 2.10 & 2.05 & 1.47 & 1.00 & 0.98 \\
Carbohydrates & & & & & & 3.46 & 5.19 & 4.32 \\
\hline
\end{tabular}

detergent fiber (NDF), and from $6.11 \%$ a $52.35 \%$ for the acid detergent fiber (ADF). Lignin content ranged from $4.33 \%$ to $14.32 \%$, between plant species, which showed that E. pubescens and Croton sp. had a high percentage of indigestible materials. The cell content (soluble parts of the plant) ranged from $25.04 \%$ to $81.77 \%$, and Y. periculosa fruits had the highest value for cell content (Table 3).

Protein/fiber ratio. The protein/fiber ratios of the plant species that the squirrels included in their diet differed significantly from each other (interval: 0.09 to 2.20 ). The plant species that showed a low protein/fiber ratio, and thus were of low nutritional quality, included B. scorpioides ( 0.09

Table 3. Approximate chemical value expressed in percentage for each plant species consumed by $X$. s. perotensis (values reported in dry material). Humidity $(\mathrm{H})$, Dry material (DM), Crude protein (CP), Ether extract (EE), Acid detergent fiber (ADF), Neutra detergent fiber (NDF), Cell content (CC), Hemicellulose (H), Cellulose (C), Lignin (L).

\begin{tabular}{lcccccccccc}
\hline \multicolumn{1}{l}{ SPECIES } & $\mathrm{H}$ & $\mathrm{DM}$ & $\mathrm{CP}$ & $\mathrm{EE}$ & $\mathrm{ADF}$ & $\mathrm{NDF}$ & $\mathrm{CC}$ & $\mathrm{H}$ & $\mathrm{C}$ & $\mathrm{L}$ \\
\hline Erigeron pubescens & 5.74 & 94.26 & 13.43 & 6.11 & 6.11 & 42.16 & 57.84 & 8.24 & 15.24 & 11.62 \\
Croton sp. & 5.46 & 94.54 & 13.56 & 8.92 & 41.24 & 50.40 & 49.60 & 9.16 & 21.32 & 14.32 \\
Scleropogon brevifolius & 4.58 & 95.42 & 8.75 & 3.70 & 48.34 & 70.75 & 29.25 & 22.41 & 14.54 & 10.08 \\
Bouteloua scorpioides & 3.60 & 96.40 & 4.88 & 3.03 & 52.35 & 74.96 & 25.04 & 21.71 & 20.63 & 5.60 \\
Verbena bipinnatifida & 5.17 & 94.83 & 15.06 & 5.96 & 30.53 & 40.42 & 59.58 & 9.89 & 17.48 & 7.65 \\
Yuccapericulosa & 9.39 & 90.61 & 4.37 & 7.65 & 11.65 & 18.23 & 81.77 & 6.58 & 6.97 & 4.33 \\
\hline
\end{tabular}

$\%$ ) and S. brevifolius (0.18\%). The squirrels, however, fed on the latter, most frequently, while E. pubescens was the plant species with the highest protein/fiber ratio (2.20\%; Table 4).

\section{Discussion}

The goal of our study was to examine the food quality of the dietary items of $X$. perotensis related to seasonal variation. We found that their diet included six plant species. During the period from April to August the diet was conformed by four indigenous grass species, while from September through November the squirrels' diet included also

Table 4. Protein and fiber content as well as protein/fiber ratios and proportion of time spent feeding on the plant species included in the diet of $X$. s. perotensis.

\begin{tabular}{lrrrr}
\hline SPECIES & PROTEIN \% & FIBER (ADF) \% & PROTEIN/FIBER \% & \% TIME OF FEEDING \\
\hline Erigeron pubescens & 13.43 & 6.11 & 2.20 & 10.54 \\
Croton sp. & 13.56 & 41.24 & 0.33 & 6.69 \\
Scleropogon brevifolius & 8.75 & 48.34 & 0.18 & 63.69 \\
Bouteloua scorpioides & 4.88 & 52.35 & 0.09 & 2.33 \\
Verbena bipinnatifida & 15.06 & 30.53 & 0.49 & 10.61 \\
Yucca periculosa & 4.37 & 11.65 & 0.38 & 6.12 \\
\hline
\end{tabular}


fruits of two plants (B. scorpioides and Y. periculosa). It is likely that the low diversity of plant species in the diet of $X$. s. perotensis is due to the small range of species that are available for consumption in their habitat.

With regard to the food resource availability, S. brevifolius had the highest vegetation cover during the sample period (May, August and November), and it was the most consumed item. Several studies performed on rodents showed that the plant species with a high vegetation cover are also the most consumed food items (Cortes et al. 2002; Matamoros-Trejo and Cervantes 1992). Our results coincide with those reported by Valdéz and Ceballos (1991), who found that the composition of the diet of the terrestrial squirrel Spermophilus mexicanus varied in relation to the phenological changes and the availability of the plants, the same pattern has been shown in meadow vole (Microtus pennsylvanicus) and ground squirrels (Urocitellus beldingi; Bergeron and Jodoin 1987; Eshelman and Jenkins 1989).

Regarding nutritional quality of the plant species used as food by the Perote's squirrels expressed as protein/fiber ratio, the species B. scorpioides and S. brevifolius had the lowest quality ( 0.09 and 0.18 respectively). In general terms, we considered that with exception of $E$. pubescens and the fruits of $Y$. periculosa the rest of the items that comprise the squirrels'diet are low quality items. A vegetarian diet is considered to be of low quality when it presents high fiber contents (mainly acid detergent fiber), including lignin, which are difficult to digest (Mc Donald et al. 1995; Quan-Sheng and De-Hua 2007). However, although S. brevifolius was of low dietary quality it was nevertheless both the most abundant and most consumed plant species, suggesting that Perote's squirrels are opportunistic feeders, as they exploit the most available food resources.

The highest percentage of protein intake was recorded during the summer months from June through September, due to the increased consumption of $E$. pubescens, the plant species with the highest quality, according to the protein/fiber ratio among the six species consumed by the squirrels. Interestingly, E. pubescens was consumed most during the period of pregnancy and lactation in the females (Valdéz and Ceballos 1997), and according to literature reports the emergence of young juvenile squirrels (Ceballos and Oliva 2005). The increase in protein consumption is therefore likely to have served to meet the increased nutritional requirements of pregnant and lactating females. Increased protein consumption during pregnancy and lactation has been found to occur in other mammals as well (e. g., Mantled howler monkeys, Alouatta palliata Serio-Silva et al. 1999; common degu, Octodon degus, Veloso and Bozinovic 2000) and thus seems to be a common pattern among mammals (McNab 1986; Pianka 1981). The Perote squirrel has been reported to also consume insects (Valdéz and Ceballos 2005), which serve as a source of protein, however, no insect consumption was observed during this study.

We recorded a higher level of fiber intake during September through November, compared to the period between April and August. During the same time window protein consumption decreased. The high proportion of fiber intake during autumn could be the result of the lower availability of other plant resources in this season. This in turn may 'force' the squirrels to feed on resources with a higher fiber content in their diet. During these months, however, consumption of $Y$. periculosa fruit was recorded. Although yucca fruits do not have high protein contents, they do have high contents of metabolizable energy in the form of carbohydrates, which increases with ripening (Baraza et al. 2008). Thus, these fruits may play an important role to meet the energy requirements and prepare the squirrels for hibernation during the low temperatures period from November to February. The mature seeds of $Y$. periculosa also contain high concentrations of non-structural lipids and carbohydrates (García-Villanueva 1986), and this may contribute to the caloric increase of the squirrels before hibernation.

Our results show a connection between plant availability and their consumption by $X$. perotensis, with the plant species having the widest cover and availability during the data collection period being the most consumed one. It appears that Perote's squirrels were able to adjust their consumption of different plant species to meet certain physiological requirements, across the breeding season and during lactation, which both require a high-energy intake. This may explain the increase in protein intake during this period, and to prepare themselves for hibernation by including high amounts of simple sugars in their diets. Our study contributes relevant information on the diet and feeding behavioral strategies that the Perote squirrels use to adapt to and survive in an environment with limited resources.

\section{Acknowledgements}

We thank CONACYT for the grant J. C. H. H. (235981).

\section{Literature Cited}

Álvarez-Castañeda, S. T., T. Lacher, and E. Vázquez. 2016. Xerospermophilus perotensis. The IUCN Red List of Threatened Species 2016 (accessed 10.01.17).

AOAC. 1990. Official Methods of Analysis. 15TH Edition, Association of Official Analytical Chemist, Washington, U. S. A. AOAC. 2012. Official Methods of Analysis of AOAC international. $19^{\text {th }}$ edition. AOAC International. Gaithersburg, U. S. A.

Baraza, E., S. Ángeles, A. García, and A. Valiente-Banuet. 2008. Nuevos recursos naturales como complemento de la dieta de caprinos durante la época seca, en el Valle de Tehuacán, México. Interciencia 33:891-896.

Belovsky, G. E. 1978. Diet optimization in a generalist herbivore: the moose. Theoretical Population Biology 14:105-134.

Benítez, V., M. BorgniA, AND M. H. CAssini. 2006. Ecología nutricional de la vicuña (Vicugna vicugna): Un caso de estudio en la Reserva Laguna Blanca, Catamarca. Pp. 1-17, in Investigación, conservación y manejo de vicuñas (Vilá, B., ed.). Buenos Aires, Argentina.

BERGERON, J. M., AND L. JoDOIN. 1987. Defining "high quality" food resources of herbivores: The case for meadow voles (Microtus pennsylvanicus). Oecologia 71:501-517. 
Best, T. L., and G. Ceballos. 1995. Spermophilus perotensis. Mammalian species 507:1-3.

Ceballos, G., And G. Oliva. 2005. Los mamíferos silvestres de México. Fondo de Cultura Económica y Comisión Nacional para el Conocimiento y Uso de la Biodiversidad (CONABIO), México.

Chapman, C. A., And L. J. Chapman. 2000. Constraints on group size in red colobus and red-tailed guenons: Examining the generality of the ecological constraints model. International Journal of Primatology 21:565-585.

Cortes, A., J. M. Rau., E. Miranda, and J. E. Jiménez. 2002. Hábitos alimenticios de Lagidium viscacia y Abrocoma cinerea: roedores sintópicos en ambientes altoandinos del norte de Chile. Revista Chilena de Historia Natural 75:583-593.

Dearing, M. D., W. J. Foley, and W. S. McLean. 2005. The influence of plant secondary metabolites on the nutritional ecology of herbivorous terrestrial vertebrates. Annual Review of Ecology. Evolution and Systematics 36:169-189.

Eshelman, B. D., AND S. H. Jenkins. 1989. Food selection by belding's ground squirrels in relation to plant nutritional features. Journal of Mammamlogy 70:846-852.

Felton, A. M., A. Felton, D. Raubenheimer, S. J. Simpson, W. J. Foley, J. T. Wood, And D. B. Lindenmayer. 2009. Protein content of diets dictates the daily energy intake of a free-ranging primate. Behavioral Ecology 20:685-690.

Freeland, W. J., and D. H. Janzen. 1974. Strategies in herbivory by mammals: the role of plant secondary compounds. The American Naturalist 108:269-289.

GARCía, E. 1973. Modificaciones al sistema de clasificación climática de Köppen. Instituto de Geografía, Universidad Nacional Autónoma de México. Ciudad de México, México.

García-García, J. L., and A. Santos-Moreno. 2014. Variación estacional en la diversidad y composición de ensambles de murciélagos filostómidos en bosques continuos y fragmentados en Los Chimalapas, Oaxaca, México. Revista Mexicana de Biodiversidad 85:228-241.

García-Villanueva, E. 1986. Anatomía de la semilla madura de Yucca periculosa, Baker (Agavaceae) y ontogenia de su tejido de reserva (Tesis de Licenciatura). Universidad Nacional Autónoma de México. Ciudad de México, México.

Grier, J. W., AND T. BuRk. 1992. Biology of Animal Behaviour. Mosby Year Book. St. Louise, U. S. A.

Gutiérrez, G. 1998. Estrategias de forrajeo. Pp. 359-381, in Manual de análisis experimental del comportamiento. (Ardila, R., W. López, A. M. Pérez, R. Quiñones, and F. Reyes, eds.). Psicología Universidad. Madrid, España.

$\mathrm{HIRSCH}_{1}$ B. T. 2009. Seasonal variation in the diet of ringtailed coatis (Nasua nasua) in Iguazu, Argentina. Journal of Mammalogy 90:136-143.

Karasov, W. H., D. Phan, J. M. Diamond, and F. L. Carpenter. 1986. Food passage and intestinal nutrient absorption in hummingbirds. The Auk 103:453-464.

Martin, P., and P. Bateson. 1993. Measuring behavior: an introductory guide. Cambridge University Press. Cambridge, United Kingdom.

Matamoros-Trejo, G., and F. A. Cervantes. 1992. Alimentos de los roedores Microtus mexicanus, Reithrodontomys megalotis y Peromyscus maniculatus del ex-lago de Texcoco, México. Anales del Instituto de Biología, Serie Zoología 63:135-144.
MATTSON, W. J. 1980. Herbivory in relation to plant nitrogen content. Annual Review of Ecology and Systematics 11:119-161.

Mc Donald, P., R. A. Edwards, J. F. D. Greenhalgh, and C. A. Morgan. 1995. Animal Nutrition. Prentice Hall. New York, U. S. A.

$M_{C} N_{A B}, B$. K. 1986. The influence of food habits on the energetics of eutherian mammals. Ecological Monographs 56:1-19.

Miranda, F., and E. Hernández-X. 1963. Los tipos de vegetación de México y su clasificación. Boletín de la Sociedad Botánica de México 28:29-179.

Owen-Smith, P., and N. Novellie. 1982. What should a clever ungulate eat? American Naturalist 119:151-178.

Penezić, A., AND D. ĆIRović. 2015. Seasonal variation in diet of the golden jackal (Canis aureus) in Serbia. Mammal Research 60:309-317.

PIANKA, E. R. 1981. Resource acquisition and allocation among animals. Pp. 300-314, in Physiological ecology: an evolutionary approach to resource use (Towsend, C.R., and P. Calow, eds.). Blackwell Scientific Publishers. Oxford, United Kingdom.

Quan-Sheng, L., AND W. De-HuA. 2007. Effects of diet quality on phenotypic flexibility of organ size and digestive function in mongolian gerbils (Meriones unguiculatus). Journal of Comparative Physiology 177:509-518.

RAUbenHeImeR, D., AND S. J. Simpson. 2004. Organismal stoichiometry: quantifying non independence among food components. Ecology 85:1203-1216.

Rezsutek, M. J., And G. N. Cameron. 2011. Diet selection and plant nutritional quality in Attwater's pocket gopher (Geomys attwateri). Mammalian Biology 76:428-435.

Robbins C.T., J. K. Fortin, K. D. Rode, S. D. Farley, L. A. Shipley, and L. A. Felicetti. 2007. Optimizing protein intake as a foraging strategy to maximize mass gain in an omnivore. Oikos 116:1675-1682.

Sandoval, J. M. 1984. Estudio de la vegetación de la sierra de Mastaloyan, Veracruz-Puebla. Tesis de licenciatura. Universidad Veracruzana. Xalapa, Veracruz, México.

SCHAIK, P., AND D. K. BRockman. 2005. Seasonality in primate ecology, reproduction, and life history: an overview. Pp. 3-20, in Seasonality in primates, studies of living and extinct human and non-human primates (Brockman, D. K., and C. P. Van Schaik, eds.). Cambridge University Press. Cambridge, United Kingdom. Schoener, T. W. 1971. Theory of feeding strategies. Annual Review of Ecology and Systematics 2:369-404.

SEMARNAT. 2010. Norma Oficial Mexicana NOM-059SEMARNAT-2010. Protección ambiental-Especies nativas de México de flora y fauna silvestres. Categoría de riesgo y especificaciones para su inclusión, exclusión o cambio. Diario Oficial de la Federación, Ciudad de México, México.

Serio-Silva, J., L. T. Hernández-Salazar, and V. Rico-Gray. 1999. Nutritional composition of the diet of Alouatta palliata mexicana females in different reproductive states. Zoo Biology 18:507-513.

Stephens, D. W., And J. R. KreBs. 1986. Foraging theory. Princeton University Press. Princeton, U. S. A.

TSindi. M. F., O. L. KupIKA, M. Moses, AND M. Simbarashe. 2016. Seasonal variation in population structure and status of selected herbivores in the Mana Pools National Park Flood Plain, Zimbabwe. Poultry, Fisheries and Wildlife Sciences 4:1-11. 
Ulappa, A. C., R. G. Kelsey, G. G. Frye, J. L. Rachlow, L. A. Shipley, L. Bond, X. Pu, AND J. S. ForbeY. 2014. Plant protein and secondary metabolites influence diet selection in a mammalian specialist herbivore. Journal of Mammalogy 95:834-842.

VALDÉS, M. 2003. Las ardillas de México. Biodiversitas 51:8-11.

ValdÉz, M., AND G. Ceballos. 1991. Historia natural, alimentación y reproducción de la ardilla terrestre (Spermophilus mexicanus) en una pradera intermontana. Acta zoológica mexicana (n. s.) 43:1-31.

Valdéz, M., and G. Ceballos. 1997. Conservation of endemic mammals of México: The Perote Ground Squirrel (Spermophilus perotensis). Journal of Mammalogy 78:74-82.

Valdéz, M., and G. Ceballos. 2005. Spermophilus perotensis Merriam, 1893. Pp. 568-569, in Los mamíferos silvestres de México (Ceballos, G., and G. Oliva, eds). Fondo de Cultura Económica y Comisión Nacional para el Conocimiento y Uso de la Biodiversidad (CONABIO), México.

VAN SoESt, P. J. 1967. Development of a comprehensive system of feed analysis and its application to forages. Journal of animal science 26:119-128.

Velázquez, A., C. Medina-García, E. Durán-Medina, A. Amador, and L. F. Gopar-Merino. 2016. Standardized hierarchical vegetation classification: Mexican and global patterns. Springer. Berlin, Germany.

Veloso, C., ANd F. Bozinovic. 2000. Effect of food quality on the energetics of reproduction in a precocial rodent, Octodon degus. Journal of Mammalogy 81:971-978.

Westoby, M. 1978. What are the biological bases of varied diets? American Naturalist 112:627-631.

WHITE, T. C. R. 1993. The inadequate environment: nitrogen and the abundance of animals. Springer-Verlag. New. York, U.S. A.

Wikum, D. A., AND G. F. Shanholtzer. 1978. Application of the Braun-Blanquet Cover-Abundance scale for vegetation analysis in land development studies. Environmental Management 2:323-329.

Associated editor: Mariana Freitas Nery

Submitted: November 19, 2017; Reviewed: January 17, 2018;

Accepted: March 24, 2017; Published on line: April 24, 2018. 
